\title{
BRONZOVÉ SÚČASTI SLÁVNOSTNÉHO KROJA ŽIEN STREDODUNAJSKEJ MOHYLOVEJ KULTÚRY
}

\begin{abstract}
Andrea Slaná
DOI: https://doi.org/10.31577/szausav.2019.suppl.1.26

Keywords: Middle Bronze Age, Middle Danube-Carpathian region, Middle Danube Barrow culture, female costume, diadems, necklaces, bracelets, jewellery sets, higher social status

Bronze components of ceremonial female costume of the Middle-Danube Barrow culture

There is no reason to doubt the existence of social elite during the time of the middle Bronze Age. Female costume and in our area mainly its preserved anorganic components show clear evidence that women played a significant role in the society of that time. Even though the nature of the jewellery and the costume components is rather similar in the territory of the barrow cultures of the Middle Danube-Carpathian region, the individual burial grounds can still illustrate their jewels' garniture peculiarities. These report on the design of a ceremonial burial garments. Some unique artefacts emerge in the burial grounds such as diadems, ornamental cross plates, necklaces and bracelets. The focus of this contribution is the study of the published anorganic, mostly bronze components of the costume for women with higher social status buried in the necropolises of the Middle Danube Barrow culture.
\end{abstract}

\section{ÚVOD}

Počiatok strednej doby bronzovej sa spája s kultúrno-historickými zmenami v takmer celej strednej Európe. Jedným z charakteristických javov je vystúpenie mohylových kultúr. Nástupom tejto epochy sa otvorili nové možnosti v charaktere a spôsobe odievania. Stredodunajsko-karpatská oblast' sa nevyznačuje podobnými priaznivými podmienkami, najmä geologickými a pedologickými, ako napríklad rašeliniská v severských močiaroch, prípadne v iných oblastiach. Preto pri rekonštrukcii ženského kroja, s prihliadnutím na vyššie sociálne postavenie jeho nositeliek, je nutné vychádzat zo spracovania jeho anorganických častí, predovšetkým šperkov. Nevyhnutné je tiež prihliadat na príslušné antropologické analýzy, ktoré potvrdzujú výbavu ženského hrobu, prípadne hrobové celky s typickými ženskými atribútmi. $\mathrm{V}$ prípade hrobov $\mathrm{s}$ kostrovým pohrebným rítom je podstatné uloženie nálezov $\mathrm{v}$ hrobovej jame, a z toho vyplývajúce umiestnenie na odeve. Pri hroboch so žiarovým spôsobom pochovávania je možné na základe určitých indícií a porovnaní s hrobmi s kostrovým rítom predpokladat pravdepodobné umiestnenie nálezov. Rekonštrukcia šiat, odevu či kroja už bola mnohokrát spracovaná, a táto tematika je stále aktuálna. Jednou z čŕt publikovaných archeologických prác je však značná terminologická nejednotnost', ktorá súvisí skôr s etnografickým poňatím problému. V predloženom príspevku používam termín kroj na označenie slávnostnej a symbolickej podoby odevu. Kroj v praveku môže byt charakterizovaný ako sprostredkovaný znak tradícií konkrétnej spoločnosti, pričom obsahuje všetky viditel’né spolunáležitosti komunity a zároveň odráža spoločenské postavenie nositela. Odzrkadluje aj ekonomickú základňu komunity a očividne podlieha určitým konvenciám (Furmánek/Veliačik/Vladár 1991, 303). Dôležitým aspektom je tiež celkové materiálové bohatstvo jednotlivých lokalít. Situácia a vybavenost' hrobov na "bohatej" lokalite bude samozrejme odlišná, ako na lokalite "chudobnejšej." Odlišnost’ spočíva tiež v množstve a kvalite, prípadne vzácnosti materiálu, z ktorého sú ozdoby šiat, alebo tela vyhotovené. Predmetom skúmania sú archeologické nálezy zo strednej doby bronzovej, z karpatsko-stredodunajskej oblasti, z územia osídleného ludom stredodunajskej mohylovej kultúry (d’alej SMK). Artefakty spracované v príspevku pochádzajú z obsahov vybraných hrobových celkov z nekropol Pitten, Viedeň 23-Sulzengasse, Borotice, Smolenice a z hromadného nálezov bronzových predmetov v Mušove (tabela 1). 
Tabela 1. Inventár spracovaných hrobových celkov a depotu z lokalít SMK s určením veku pochovaných jedincov.

\begin{tabular}{|c|c|c|c|}
\hline Lokalita & Hrob & Vek & Inventár \\
\hline Pitten & $\mathrm{H} 2$ & $35-40$ & $\begin{array}{l}\text { krížová platnička } 2 \text {, ihlica } 2 \text {, terčovitý závesok } 11 \text {, závesky krížového tvaru } 2 \text {, prsteň } 4 \text {, špirálové } \\
\text { trubičky (celková dížka } 1,64 \text { m), bronzové krúžky } 2 \text {, bronzové dlátko } 1 \text {, hlinená perla } 1 \text {, hlinený } \\
\text { korálik } 1 \text {, hrncovitá nádoba } 1\end{array}$ \\
\hline Pitten & H 26a & $30-35$ & diadém 1, ihlica 2 , závesok srdcovitý 1 , špirálové trubičky 6 , hrniec \\
\hline Pitten & H 57 & $12-13$ & ihlica 2, závesok terčovitý 10 , závesok kónický 6 , špirálové trubičky, črepy z 2 nádob \\
\hline Pitten & H 98 & $16-20$ & $\begin{array}{l}\text { ihlica } 2 \text {, závesok terčovitý } 7 \text {, závesok kónický } 3 \text {, špirálové trubičky } 8 \text {, prsteň } 1 \text {, fragmenty } \\
\text { prsteňov, črep } 1\end{array}$ \\
\hline Pitten & H 111a & $35-45$ & diadém 1, ihlica 3, bronzové krúžky (náušnice) 2, črepy z 2 nádob \\
\hline $\begin{array}{l}\text { Viedeň 23, } \\
\text { Sulzengasse }\end{array}$ & $\mathrm{H} 1$ & $15-16$ & ihlica 2 , závesok terčovitý 18 , nárameník 2 , nánožník 2 , fragment špirálovej trubičky \\
\hline Borotice & H 1/mohyla 9 & & náramok 4, ihlica 2, závesok 1 \\
\hline Smolenice & H 13/mohyla 6 & & $\begin{array}{l}\text { ihlica } 4 \text {, náramok } 12 \text {, zvitok zlatého drôtu 2, bronzový zliatok, popolnica } 2 \text {, šálka, amforka, črepy } \\
\text { misiek }\end{array}$ \\
\hline Mušov & depot & & zlomok ihlice 1, bronzová špirála \\
\hline
\end{tabular}

\section{KROJ ŽIEN S VYSOKÝM STATUSOM NA POHREBISKÁCH SMK}

Do popredia vystupuje lokalita Pitten. Tu sa našli už dostatočne známe a publikované tri diadémy, ktorých analógie sa $\mathrm{v}$ oblastiach rozšírenia mohylových kultúr a v susedných oblastiach zatial' neobjavili. Zriedkavý výskyt diadémov $\mathrm{v}$ hroboch a depotoch SMK, v porovnaní $\mathrm{s}$ inými častami kroja dokladá výnimočnost̉ týchto nálezov. Objavujú sa v takej malej miere, že nepopieratelne dokumentujú zvláštne postavenie jeho nositeliek v spoločnosti (Schumacher-Matthäus 1985, 77, 78). Aj ked' pittenská nekropola disponuje celým radom nezvyčajných bronzových predmetov, diadémy a ozdobné krížové platničky v tvare maltézskeho kríža môžu byt̉ označené ako unikátne nálezy (Hampl/Kerchler/Benkovsky-Pivovarová 1985, 57). Výrobcovia týchto predmetov kládli dôraz na honosnost', vysokú remeselnú a estetickú úroveň. Ich praktická funkcia bola často potláčaná (Furmánek/Ožd’áni 2015, 153). Pozornost’ si zaslúžia diadémy pochádzajúce $z$ hrobov 26a, 111a. Oba hroby sa vyznačovali výnimočnou výbavou. Diadém z hrobu 111a (tab. I: 1) sa našiel v hrobe 35 až 45-ročnej ženy, napravo od lebky. Bol vyrobený z hrubého plechu, s prinitovanou opierkou hlavy. Obruč i opierka boli bohato zdobené gravírovaným ornamentom. Výzdobný motív pozostáva z girlandovite vinúcich sa línií, ktoré sa kombinujú s tzv. „slnečným motívom". Súčastou výbavy hrobu bola aj bronzová ihlica s dvojkónickou hlavicou, mierne zhrubnutým krčkom s otvorom a profilovanou ihlou. Nachádzala sa na vnútornej strane pravého predlaktia. Na základe ihlice bol diadém datovaný do staršej fázy mohylovej kultúry MD II/B III b (SchumacherMatthäus 1985, 77). Inventár hrobu obsahoval ešte dve ihlice. Ihlica s malou platňovitou hlavicou (tab. 1: 2) bola umiestnená na vnútornej strane lavého nadlaktia. Druhá, s dvojkónickou hlavicou, bola na vnútornej strane pravého nadlaktia (tab. I: 3). Tretia ihlica rovnakého typu (tab. I: 4) ležala pri lavom kolene. V oblasti uší sa nachádzali dva krúžky (Noppenringe) zo špirálovite stočeného drôtu (Hampl/ Kerchler/Benkovsky-Pivovarová 1978-1981, 66, 69, tab. 49; 50; 130; 131; 134; 216; 217). Taktiež v hrobe 26 sa nachádzal podobný diadém 30-35-ročnej ženy (tab. II). Zaujímavé je, že i v tomto prípade bol uložený napravo od lebky. Okrem diadému sa tu nachádzala ihlica s pečatidlovou hlavicou, ktorá bola umiestnená horizontálne s lavým plecom, s hrotom smerujúcim doprostred tela. Paralelne s lavým nadlaktím išla druhá ihlica s klincovitou hlavicou a hrotom smerujúcim ku hlave. Nad a pod telom pochovanej ženy sa nachádzali špirálovité trubičky, pri krku ležal srdcovitý závesok. Na základe sprievodných ihlíc je možné zaradenie diadému do mladšej fázy mohylovej kultúry MD III/B IVa (Hampl/Kerchler/ Benkovsky-Pivovarová 1978-1981, 89, 31, tab. 25; 26; 119; 120; 195; 203; 204; Schumacher-Matthäus 1985, 77, 88). Do rovnakého obdobia sa začleňujú aj diadémy z Csabrendeku a Nagybátonu (Mozsolics 1973, 125, tab. 1; Patay 1954, 42, 45, obr. 17: 6). Ako už bolo spomenuté, oba pittenské diadémy nemajú analógie v celej stredodunajskej oblasti. Z. Benkovsky-Pivovarová poukazuje na paralely až v oblasti Ledro v severnom Taliansku, pričom ide o podobnost’ vo vytvarovaní profilovanej obruče a opierky hlavy (Hampl/Kerchler) Benkovsky-Pivovarová 1978-1981, 59). Rozdiel je tiež v hmotnosti, pričom diadémy z Ledro sú dvakrát tažšie a predpokladá sa aj ich vyšší vek. Je pravdepodobné, že táto honosná súprava nebola určená iba na pohrebnú slávnost', ale prináležala pochovaným ženám už počas ich života. Dokladajú to jednak 
výnimočné diadémy, ale aj sprievodná výbava v hroboch. K najviac zastúpeným nálezom okrasnej, ale aj praktickej funkcie patrili na pohrebisku v Pittene ihlice, ktoré predstavujú najbežnejší funkčný šperk všetkých mohylových kultúr (Furmánek/Ožd’áni 2015, 155). Exempláre, ktoré boli spomenuté, (hrob 111 - ihlice s dvojkónickou hlavicou a s malou platňovitou hlavicou, hrob 26a - ihlice s pečatidlovou a s klincovitou hlavicou), patrili k bežnému inventáru. Ihlica s dvojkónickou hlavicou, zhrubnutým krčkom s otvorom a profilovanou ihlou sa na nekropole vyskytla v šiestich hroboch, no len v prípade hrobu 111a išlo o ženský hrob. Naproti tomu ihlice s platňovitou hlavicou pochádzajú len z hrobov žien (napr. 20a, 111a). Pri všetkých typoch ihlíc so zhrubnutým krčkom, s otvorom a profilovanou ihlou, ak však odhliadneme od ihlíc typu Wetzleinsdorf, je možné počítat' s príbuzným druhom pochovávania. Vo všetkých prípadoch ide o kostrový pohrebný rítus¹ (Hampl/Kerchler/Benkovsky-Pivovarová 1978-1981, 32, 33). Ihlice s kónickou alebo dvojkónickou hlavicou, centrálnym otvorom a profilovanou ihlou sú v oblasti rozšírenia mohylových kultúr strednej Európy datované do stupňa B1 (Furmánek 1973, 111; Hachmann 1957, 83; Holste 1953, 95-104; Innerhofer 2000, 291-294; Jílková 1958, 342; Novotná 1980, 54; Říhovský 1979, 21 n.; Torbrügge 1959, 35; Willvonseder 1937, 106 n.). Ihlice s pečatidlovou hlavicou predstavujú v Pittene najrozšírenejší typ ihlíc, pričom na území rozšírenia mohylových kultúr sú vedúcim typom rozvinutej strednej doby bronzovej. K tomuto typu bolo v Pittene priradených 29 exemplárov a všetky, až na jeden prípad, pochádzajú z uzatvorených hrobových celkov. Pre podrobnejšie členenie boli vypracované štyri varianty tohto typu ihlíc z menovanej lokality:

- A variant: s tenkou platňovitou hlavicou;

- B variant: s hrubšou, väčšinou zdobenou platňovitou hlavicou;

- C variant: s bohato profilovanou hlavicou;

- D variant: s obzvlášt vel'kou, zdobenou platňovitou hlavicou (Hampl/Kerchler/Benkovsky-Pivovarová 1978-1981, 43-45).

V jedenástich prípadoch z celkového počtu 19 hrobov nebolo možné určit pohlavie pochovaných, čo vyplýva z vysokého počtu žiarových hrobov na pohrebisku. Vo všetkých hroboch, ktoré boli definované ako ženské (s výnimkou hrobu 172) sa nachádzali po dve ihlice. Pre dané spracovanie sú dôležité $\mathrm{B}$ variant - v hrobe 29a a C variant - v hrobe 26a. Celkovo sa na pohrebisku vyskytlo dvanást' kusov variantu B, pričom priemerná dížka ihlíc bola $26,5-34 \mathrm{~cm}$. Variant C sa vyskytol šest'krát, s dížkou okolo $30 \mathrm{~cm}$. V prípade, ak sú všetky hroby s obsahom dvoch ihlíc s pečatidlovou hlavicou interpretované ako ženské, potom sa najčastejšie vyskytuje v ženských hroboch variant B. Ihlice s klincovitou hlavicou majú väčšinou zosilnenú vrchnú čast’ s centrálnym otvorom, ktorá je v niektorých prípadoch vo výške otvoru mierne zhrubnutá a pod hlavicou viac alebo menej trúbkovite rozšírená. Ukončená je plochou alebo málo oblou klincovitou hlavicou. K tomuto typu je $\mathrm{v}$ Pittene priradených dvadsat ihlíc a ich úlomkov. Nachádzali sa v štrnástich hroboch. Vyskytovali sa tak $\mathrm{v}$ ženských, ako aj v mužských hroboch. V ženských hroboch sa objavovali bud' dve ihlice tohto typu (hroby 2, 57 a 98), alebo jedna v kombinácii s iným typom. K d’alšej vel'mi významnej skupine patria hroby s ozdobnými platňami v tvare maltézskeho kríža. Na lokalite sa zachovalo pät exemplárov. Ide o rovnoramenný kríž, mierne vypuklého tvaru, zdobený gravírovaním, so stredovým tŕňom na vonkajšej strane a uškom v strede vnútornej strany. Pravdepodobne slúžili ako závesky. Dva exempláre pochádzajú zo ženského hrobu 2 (tab. III: 11, 12). V porušenom mužskom hrobe 52 bol iba jeden. Zvyšné dva sa objavili na parcele 372 spolu s dvoma wetzleinsdorfskými ihlicami a naznačujú tak opät možnost̉ ženského hrobu. Jednoznačné však je, že tvorili súčast ženského, ale i mužského odevu. Vo všetkých prípadoch sa vel'kost̉ pohybovala od $9,2 \mathrm{~cm}$ do 10,5 cm (Hampl/Kerchler/Benkovsky-Pivovarová 1978-1981, 60). Z hladiska hrobového inventára je dôležitý už spomínaný hrob 2, ktorý obsahoval bohatú výbavu. Ide o hrob dospelej ženy (adultus). Jedna ozdobná platnička ležala pri krku pochovanej, d’alšia v oblasti pravého bedra. Dve ihlice s klincovitou hlavicou a otvorom na ihle ležali v rebrovom oblúku, pričom hroty smerovali k hrudníku. Štyri prstene z bronzového drôtu s ružicovite stočenými koncami sa nachádzali v mieste nad kostami ruky, pričom tie boli v oblasti panvy. Jedenást’ bronzových terčovitých záveskov s koncentrickými rebrami bolo roztrúsených v celej hornej polovici skeletu. Čast’ nad a čast' pod kostrou (tab. III: 1-10). Rovnako tak i bronzové drôtené špirálové trubičky, ktorých celková dĺžka dosahovala 1,64 m. Tieto predmety pravdepodobne slúžili ako nášivky na odev. Hlinené perly ležali v blízkosti pravého ramena (Hampl/Kerchler/ Benkovsky-Pivovarová 1978-1981, 17, 18, tab. 10). Spôsob nosenia ozdobných platničiek sa dá len tažko interpretovat. Výskyt tohto druhu ozdôb sa obmedzuje len na lokalitu Pitten. Všetky exempláre majú príbuznú výzdobu, avšak v hrobe 2 sa odlišujú pomerne dlhým špicatým stredovým tŕňom a líniou čiar

Hroby 20a, 111a, 111b, 148a, 148b, 154b, 181b a 186d. 
ohraničujúcich ramená kríža. Na základe sprievodných ihlíc sú prirad’ované k počiatočnej fáze mohylovej kultúry. Vzhladom na ojedinelost̉ týchto nálezov Z. Benkovsky-Pivovarová uvažuje o možnosti domácej výroby, teda existencii dielní (Hampl/Kerchler/Benkovsky-Pivovarová 1978-1981, 60). Svedectvo o slávnostnom kroji pochovaných žien poskytujú i hroby 57 a 98 . V hrobe 57 bolo pochované dievča (infans II - približne 12-13 rokov). V okolí pravej spánkovej kosti bolo objavených šest’ vysokých kónických záveskov z bronzového plechu, ktoré boli navzájom lúčovite rozložené. Hroty smerovali ku sebe (tab. IV: 1-6). Naprieč, smerom ku koncom záveskov ležala jedna špirálová trubička. Pokial ide o spôsob použitia a aplikovania vysokých kónických záveskov na odev, bolo v minulosti prezentovaných niekol'ko názorov. A. Mozsolicsová ich považovala za chrániče hrotov ihlíc, W. A. Brunn za predmety, ktoré mali funkciu akýchsi zvončekov (v. Brunn 1976, 492; Mozsolics 1967, 85; Paulík 1986, 82). V danom prípade predpokladám, že šnúra alebo strapec mohol byt̉ ukončený týmto záveskom, pričom uzlík zostával skrytý vo vnútri a zároveň zabraňoval zošmyknutiu. Spôsob takéhoto použitia dokladá i nález z mohylníka v Líštanoch, v západných Čechách. Plechový závesok preberaného typu bol zavesený na koženom remienku s uzlíkom na konci (Bašta/Baštová/Metlička 1990, 153, obr. 5: 4). Ak hladáme paralelu k umiestneniu pri hlave, je možné poukázat’ na exempláre zo Stockerau (Angeli 1961, 141, tab. 7, 8; BenkovskyPivovarová 1994, 21-23; Nevizánsky/Prohászka 2017, 198, obr. 3: 3). Tie sú však zhotovené zo špirálovite stočeného drôtu a vyskytujú sa v prostredí kultúr včasnej doby bronzovej. Príležitostne sa vyskytli spolu s diadémom. G. Schumacher-Matthäusová (1985, 87, tab. 56: 1b) uvažuje o možnosti prevlečenia šnúry záveskami a pri jej stiahnutí predpokladá tzv. vejárovité rozloženie jednotlivých kusov. Na základe analógií z pohrebiska v Mezöcsáte (Hänsel/Kalicz 1986), kde je doložené používanie pohrebných pláštov vytiahnutých až cez tvár pochovaných, uvažujem práve o existencii takéhoto plášta i v prípade hrobu 57. Šest’ vysokých kónických záveskov, vejárovite usporiadaných naznačuje stiahnutie plášta šnúrou z organického materiálu, ktorú vytváralo pravdepodobne niekol'ko tenších textilných nití. Slávnostný výzor plášta mohli dotvárat práve takéto závesky. Rozstrapenie na konci šnúry bolo zrejme stiahnuté špirálovou trubičkou, pričom jednotlivé nite šnúry boli prevlečené cez závesky. Uzlíky zabraňovali zošmyknutiu. K existencii plášta $v$ tomto prípade prispieva i skutočnost', že ozdoby hlavy, (napr. diadémy) sa na pohrebisku vyskytujú u žien vyššieho veku, 35-40-ročných. Analogické použitie plášta s prekrytím tváre sa objavuje na pohrebisku v Mezöcsáte tiež u vekovo mladších pochovaných jedincov. Hrob 66, v ktorom bolo pochované 16-17-ročné dievča, vekovo zodpovedá i preberanému hrobu z pohrebiska v Pittene (Hänsel/Kalicz 1986, 30, 32, tab. 9). Dievča pochované v hrobe 57 malo na pravom ramene a vedla, paralelne k lavému ramenu vždy jednu ihlicu, ktorých hroty smerovali do oblasti pliec. Išlo o rovnaký typ ihlíc s klincovitou hlavicou a s otvorom na ihle (tab. IV: 7, 8). Na prsiach ležal náhrdelník, ktorý pozostával z desiatich terčovitých platní a špirálových trubičiek umiestnených medzi nimi. Osem z nich bolo vel'kých a dve malé, pričom boli umiestnené na oboch koncoch (tab. IV: 9; Hampl/Kerchler/BenkovskyPivovarová 1985, 46, 47, tab. 35; 125; 209). V hrobe 98 bola pochovaná mladá žena vo veku 16-20 rokov. Hrob bol vel'mi silne porušený, ale nie vyrabovaný. V oblasti hornej polovice tela sa nachádzali dve dlhé ihlice s klincovitou hlavicou a s otvorom na ihle. Hroty smerovali k lebke. V priestore celého hrobu boli rozptýlené d’alšie nálezy. Sedem terčovitých záveskov z bronzu s koncentrickými rebrami na terči, so stredovým tŕňom a závesným uškom na okraji. Ďalej osem špirálových trubičiek, tri vysoké kónické závesky z bronzového plechu, rozlomený prsteň z bronzového drôtu s ukončením špirálovou ružicou a štyri špirálky z bronzového drôtu ako úlomky prsteňov (Hampl/Kerchler/Benkovsky-Pivovarová 1985, 60, 61, tab. 44; 213). Je zrejmé, že dominantou oboch súprav šperkov z hrobov 57 a 98 boli náhrdelníky pozostávajúce $\mathrm{z}$ terčovitých záveskov a špirálových trubičiek. Na pohrebisku v Pittene sa našlo spolu 30 terčovitých záveskov s koncentrickými rebrami (Hampl/Kerchler/Benkovsky-Pivovarová 1985, 71). Závesky sa nachádzali tiež v hrobe 2, ktorý už bol opisovaný. Devät exemplárov bolo však v tomto prípade roztrúsených nad aj pod skeletom. Všetky menované závesky pochádzajú zo ženských hrobov a sú rovnakého typu -s dlhým stredovým tŕňom a šiestimi až siedmimi koncentrickými kruhovými rebrami. Väčšie majú priemer $5,5 \mathrm{~cm}-6 \mathrm{~cm}$, menšie $4,4 \mathrm{~cm}$. Dôležité je poznamenat', že špirálové trubičky z bronzového drôtu sa našli v deviatich ženských a len v dvoch mužských hroboch. Velmi často sa vyskytovali počas strednej fázy mohylovej kultúry, ked’ sa používali obzvlášt dlhé špirálové trubičky (hroby 2, 26a, 52a, 57, 98a 157). V prípade hrobov 2 a 26a ležali vo vrchnej i spodnej časti panvy, pričom neboli umiestnené priamo na skelete. Mohli slúžit ako ozdobná súčast' lemu odevu, pravdepodobne plášta (Furmánek/Ožd’áni 2015, 156; Trogmayer 1975, 149). Svojím inventárom sa hroby 2, 26a, 111a, 57, a 98 zarad’ujú medzi významné ženské hroby nekropoly v Pittene. Možno teda uvažovat o niekol'kých vedúcich súpravách šperkov slávnostného kroja na pohrebisku, ako napríklad súpravy s diadémom a s ozdobnými krížovými platňami a súpravy s náhrdelníkmi. V prípade eponymného pohrebiska sa kroj žien s vyšším 
spoločenským statusom neobmedzoval iba na súčasti odevu a šperky bežne sa vyskytujúce, ale naopak výnimočné, a to nielen $\mathrm{v}$ prostredí rozšírenia $\mathrm{SMK}$, ale aj v celej stredodunajskej oblasti.

K d’alším klúčovým lokalitám pre poznanie bronzových častí kroja patrí Viedeň 23-Sulzengasse. Tu boli objavené dva hroby, zaradené do počiatočnej, najstaršej fázy strednej doby bronzovej. Dokladajú to najmä nálezy v hrobe 15-16-ročného dievčata. V oblasti pliec boli uložené dve kosákovité ihlice, ktorých hroty sa krížili a smerovali do oblasti okolo tváre (tab. V: 1, 2). V oblasti hrudníka ležalo 18 terčovitých záveskov (tab. V: 4-6). Na predlaktí oboch rúk sa nachádzali po jednej plechovej špirále, taktiež na oboch nohách. V tomto prípade je evidentné, že slúžili ako nárameníky (tab. V: 7, 8) a nánožníky (tab. V: 10, 11). Tri fragmenty bronzovej tyčinky ležali západne pri lavom pleci. V hrobe 2 bola pochovaná dospelá žena, tu sa však vyskytla iba jedna plechová špirála, slúžiaca ako nánožník (tab. V: 9; Hahnel 1994, 29 n., obr. 1; 3). Celá súprava slávnostného kroja dievčat’a je typickým príkladom celku zo začiatku strednej doby bronzovej. Bronzové predmety sú výrobkami karpatsko-podunajských dielní a zodpovedajú tzv. kosziderskému horizontu nálezov (Novotná 1993, 99). Charakteristickým typom bronzového inventára sú kosákovité ihlice. B. Hänsel ich rozčlenil do viacerých typologických skupín s odlišnou chronologickou platnostou (Hänsel 1968, 78 n.). V tomto prípade ide o kosákovité ihlice s prevŕtanou diskovitou, resp. hríbovitou hlavicou, ktoré zaradil do stupňa MD I, ešte pred tzv. lochhamský horizont južného Nemecka. Ihla oboch ihlíc bola kosákovite ohnutá a tordovaná. V slovenskej odbornej literatúre sa prejavila pri posudzovaní otázky chronologického postavenia kosákovitých ihlíc rozporuplnost̉ názorov, ktorá vyplýva z datovania menovaného typu do stupňa BB1 (Furmánek 1973, 110, 111; Novotná 1980, 64 n., tab. 66; Točík 1964, 52) a z nesprávnej interpretácie názorov B. Hänsela v tom zmysle, že sa síce príležitostne cituje rozdelenie kosziderského horizontu na dva stupne (MDI-MDII), pritom sa však datovanie staršieho z týchto stupňov pred stupeň BB1 neberie do úvahy (Benkovsky-Pivovarová 1984, 30 n.). K. Willvonseder považoval kosákovité ihlice, tvary s radiálnou výzdobou, za súčast' inventára najstaršej fázy mohylovej kultúry (Willvonseder 1937, 103 n.). Neskoršie nálezy však potvrdili, že tieto typy ihlíc nemožno spájat iba s nastupujúcou mohylovou kultúrou. Za charakteristický typ bronzovej industrie kosziderského horizontu považuje menované ihlice A. Mozsolicsová. Jednotlivé varianty kosákovitých ihlíc synchronizuje s Reineckeho stupňom B. Tým ich považuje za súveké, s výnimkou ihlíc so separátne odlievanou hlavicou, ktoré považuje za mladšie (Mozsolics 1967, 83, 84). Kosákovité ihlice z územia Moravy zaradili V. Furmánek $(1973,111)$ a J. Říhovský $(1979,17$ n.) do stupňa B1, pričom sa opierali o datovanie menovaného typu ihlíc z územia Rakúska K. Willvonsederom $(1937,118)$. Podstatný prínos do danej problematiky prinieslo spracovanie a vyhodnotenie nálezov na pohrebisku v Pittene, ktoré svojou počiatočnou fázou patrí nepochybne k najvýznamnejším lokalitám kosziderského horizontu. Z chronologického hladiska je možné kosákovité ihlice považovat za spolahlivé kritérium stupňa B1 (Benkovsky-Pivovarová 1984, 30 n.; 2016, 21). Súčastou výbavy hrobu dievčata z Viedne bolo tiež osemnást̉ terčovitých záveskov, opatrených z vonkajšej strany koncentrickými rebrami a stredovým výčnelkom. Niet pochýb, že vytvárali náhrdelník, ktorého existenciu dokladajú i fragmenty špirálových trubičiek, ktoré bývali zastrčené do závesných ušiek záveskov, a tým vytvárali pevnú jednotku medzi terčíkmi a zabezpečovali ich odstup. G. Schumacher-Matthäusová $(1985,100-102$, tab. 58; 70) ich považuje za charakteristickú ozdobnú formu strednej doby bronzovej. Typologicky ich rozdeluje do troch variantov, pričom opisované exempláre je možné začlenit $\mathrm{k}$ variantu so širokým rebrovaním a tupým výčnelkom. $\mathrm{V}$ tomto prípade vyniká náhrdelník množstvom záveskov. V rámci jedného kroja sa množstvo záveskov pohybovalo okolo desat’ kusov. To však nie je možné považovat za pravidlo, čo dokladá aj osemnást terčovitých záveskov preberaného hrobového inventára. Ich značné množstvo a rozmiestnenie v celej časti hrudníka navodzuje domnienku, že mohlo íst’ o viacradový náhrdelník, aké sa v období končiacej staršej a začínajúcej strednej dobe bronzovej vyskytujú. Terčovité závesky spomínaného variantu zarad’uje G. Schumacher-Matthäusová (1985, 100) podla periodizácie B. Hänsela do stupňov MDI-MDII, pričom ich synchronizuje so stupňom B IIIb podla A. Mozsolicsovej. Z obdobia kosziderského horizontu uvádza analogické nálezy z Oroszipusta, Dolného Petra (hrob 24), Dunaújváros (hroby 854a, a 884), Várpalota (hroby 4 a 7), Ráksi, Tápióbicske. Autorka považuje výskyt terčovitých záveskov varianty A za obmedzujúci sa na územie rozšírenia karpatskej mohylovej kultúry (Schumacher-Matthäus 1985, 100-102), čo možno spochybnit vzhladom k nálezom preberaného hrobového celku. Nutné je podotknút, že tak, ako na to poukazuje nálezová situácia v Pittene, čiže prevažná väčšina nálezov špirálových trubičiek, prípadne ich fragmentov sa nachádza v hroboch žien, je potvrdená i na iných lokalitách. Súvislost honosných náhrdelníkov pozostávajúcich z terčovitých záveskov a špirálových trubičiek predovšetkým so ženským krojom je jednoznačná. Ďalšími predmetmi vhodnými na datovanie sú špirály z bronzového plechového pásika s výrazným stredovým rebrom. Pokial pochádzajú tieto špirály z hrobov, väčšinou chýbajú presnejšie 
údaje o ich uložení, a tým odpadá možnost̉ spolahlivého posúdenia ich funkcie (Stuchlík 1981, 364). Lokality Viedeň 23-Sulzengasse sa tento problém netýka, pretože nálezová situácia bola vel’mi priaznivá a špirály $\mathrm{v}$ hrobe sa zachovali na pôvodných miestach (na rukách a na nohách). Plechové špirály na rukách možno interpretovat ako nárameníky. Dížka je 9,9 cm a 10,2 cm. Oba vytvára bronzový plechový pásik, štvornásobne stočený. Ukončený je na oboch koncoch identickými špirálovitými ružicami, ležiacimi v protilahlých stranách. Špirály z bronzového pásika sú z vnútornej strany ploché, a z vonkajšej opatrené výrazným stredovým rebrom. Ozdobené sú líniou vybíjaných jemných bodov, ktoré symetricky lemujú vždy len jednu stranu pásika špirály, pozdĺž stredového rebra. Nánožníky boli podstatne väčšie, a v tomto prípade neidentické. Obe špirály vytváral bronzový plechový pásik, trojnásobne stočený. Dížka jednej bola 22,3 cm a druhej $19 \mathrm{~cm}$. Plechový pás bol z vnútornej strany plochý, a z vonkajšej $\mathrm{s}$ výrazným stredovým rebrom. Nánožníky ukončovali špirálovité ružice, podstatne väčšie ako pri nárameníkoch. Výzdoba pozostávala z línií vybijaných jemných bodov lemujúcich stredové rebro symetricky, vždy pozdĺž jednej strany. Menší z dvoch nánožníkov bol ozdobený okrem vybíjaných bodov vždy v protilahlej strane pozdíž stredového rebra vlnovkovou líniou, vytvorenou taktiež z línie jemných vybíjaných bodov (Hahnel 1994, 32, obr. 3). Hrobový celok z Viedne 23-Sulzengasse, zaradili vo svojom chronologickom členení J. Lichardus a J. Vladár (1997, 221 n.) do „horizontu 8“, ktorý synchronizujú so stupňom A3, upravenej Reineckeho chronológie, a tým so strednou fázou madarovskej kultúry. Zaradenie do tohto horizontu uvedeného periodizačného systému sa však javí príliš včasné, vzhladom na charakter nálezového celku. Najmä kosákovité ihlice, ktoré autori uvádzajú ako charakteristický tvar horizontu 9 a horizontu 10, v menovanom horizonte 8 nie sú zastúpené. Nejasnosti sa týkajú okrem kosákovitých ihlíc i špirálových nárameníkov, ktoré sa vyskytujú v hromadnom náleze z Dunajskej Stredy a opät sú zaradené do horizontu 9, teda do stupňa B0 (Lichardus/Vladár 1997, 221 n.). Nie je však možné súhlasit' s jeho zaradením, ako typického reprezentanta kosziderského obdobia k počiatočnej fáze SMK, a to hlavne z dôvodu absencie iných nálezov, ktorými by na území Slovenska bolo možné doložit vznik SMK už v stupni B0 citovanej chronológie. Prikláňam sa k názoru, že počiatok strednej doby bronzovej, ktorý je reprezentovaný aj kosziderským horizontom nálezov, nemusí byt๋ bezpodmienečne spätý s nástupom mohylovej kultúry. Samostatnosṫ menovaného horizontu dokladá jeho rozšírenie nezávisle od rozšírenia určitého kultúrneho spoločenstva. Na základe týchto skutočností uprednostňujem zaradenie nálezového celku z Viedne 23-Sulzengasse, do nasledujúceho obdobia, teda do stupňa BB1. Z moravských nálezov existujú tiež paralely k preberanému hrobovému celku. Hromadný nález bronzových predmetov z Mušova, obsahoval príbuzný inventár. Okrem zlomku kosákovitej ihlice, ktorá je datovaná do stupňa BB1, obsahoval aj zlomok špirály z bronzového pásika, ukončeného ružicou (Červinka 1926, 30, obr. 2). Výzdoba je takmer identická so špirálovým nánožníkom z hrobu dievčata z Viedne. Bronzová špirála má výrazné stredové rebro. Po oboch stranách rebra sa tiahnu línie jemne vytepávaných bodov, pričom jedna je rovnobežná s rebrom a druhá vytvára vlnovku. Jeden koniec je ukončený vel'kou špirálovitou ružicou, druhý je odlomený. Materiál z mušovského depotu radí S. Stuchlík $(1981,367)$ k stredodunajskej mohylovej kultúre. Predpokladá, že pôvod bronzových plechových špirál a zlomku pochádzajúceho z najväčšou pravdepodobnostou z kosákovitej ihlice s prevŕtanou hlavicou, je možné zaradit do stupňa BB1 Reineckeho chronológie. Z moravských nálezov je zaujímavý nálezový celok z Borotíc z mohyly 9. Kostrový hrob I obsahoval štyri masívne náramky zdobené rytou výzdobou, dve terčovité ihlice, $\mathrm{z}$ toho jednu typu Wetzleinsdorf a malý závesok zo špirálovite stočeného drôtu. Celý súbor šperkov patril pravdepodobne žene a je možné ho zaradit do staršieho obdobia mohylovej kultúry (Stuchlík 1990a, 159-169; 1990b, 477, obr. 7). Ihlice typu Wetzleinsdorf, podobne ako kosákovité ihlice, sú reprezentantom stupňa BB1. Tento typ je charakterizovaný širokou plochou klincovitou hlavicou a mierne zhrubnutým krčkom. Ihla býva často štvorhranného prierezu, čo je potvrdené aj pri opisovanom exemplári. Datovanie nálezového celku podporujú tyčinkové náramky trojuholníkovitého prierezu, ktoré sú zdobené charakteristickým ornamentom stupňa BB1. Príbuzný nález, ihlica typu Wetzleinsdorf s dvomi tyčinkovými náramkami trojuholníkovitého prierezu, bola objavená v Pasohlávkach (Furmánek 1973, 111, 118, 119, obr. 40: 5-7, 9-11). Konce starších typov bývajú pečatidlovite rozšírené, čo je badatelné u jedného z náramkov. Geometrická výzdoba je tvorená zväzkami rovnobežných rýh a oblúčikov. Podobná výzdoba je na náramkoch z hromadného nálezu z lokality Rácegres (Hänsel 1967, 275-289, tab. 14: 36, 37), ktorý je tiež datovaný do stupňa BB1. Analogické nálezy pochádzajú aj z rakúskej lokality Eisbesthal (Hänsel 1967, 275-289, tab. 14: 36, 37). Menovaný typ náramkov je možné označit za typ reprezentujúci staršiu fázu stredodunajskej mohylovej kultúry (Furmánek 1973, 119). Súprava opisovaných šperkov pravdepodobne zdobila ženu s vyšším spoločenským postavením a je možné jej zaradenie do stupňa BB1. Lokalitou, ktorá poskytuje dôležité svedectvo o existencii SMK na Slovensku, je pohrebisko 
v Smoleniciach. Výbave ženského hrobu zodpovedá napríklad žiarový hrob 13 z mohyly 6, ktorý bol objavený čiastočne pod hrobom 12. Nachádzali sa tu dve poškodené popolnice. V oboch boli objavené kalcinované kosti. V popolnici 1 boli uložené dva bronzové náramky (tab. VI: 2, 5), vedla nej šest’ náramkov, z toho pät celých a jeden s odlomeným koncom (tab. VI: 3, 4, 8). V popolnici 2 boli dve bronzové ihlice (tab. VI: 11, 12), štyri bronzové náramky (tab. VI: 9, 10, 13, 14), dva zvitky zlatého drôtu, bronzový zliatok (tab. VI: 7) a d’alšie dve bronzové ihlice (tab. VI: 1, 6). Početne sú zastúpené najmä náramky trojuholníkovéitho prierezu s rozšírenými neuzatvorenými koncami a strechovite vyklenutou hornou plochou, zdobené jednoduchými alebo dvojitými polkruhmi. Podobný náramok bol na pohrebisku aj v žiarovom hrobe 70 . V žiarovom hrobe 13 a kostrovom hrobe 35 sa nachádzali náramky s tzv. motívom rybieho mechúra. (Dušek 1980, 342-344, 368, 369, tab. I: 14-16; II: 1-14). Podobné náramky sa zistili aj na lokalitách v Obide a Čáčove na juhozápadnom Slovensku (Eisner 1933, tab. XXXVI: 1, 6-12, 14, 16; Novotná 1999, 241 n.; Pichlerová 1956, tab. XXVI: 2). Výskyt podobných náramkov s príbuznou výzdobou je badatelný hlavne na Morave, napríklad na lokalitách Klentnice, Šatov, Pasohlávky, Klobouky a Oblekovice (Furmánek 1973, 118, 119). Z Rakúska uvádza K. Willvonseder podobné náramky z Trandorfu, Winklarnu a Kronstorfu (Willvonseder 1937, tab. 28: 4; 35: 1, 4; 45: 9). Výnimočnost̉ inventára dokladajú dva zvitky zlatého drôtu, ktoré boli uložené $\mathrm{v}$ kalcinovanej kosti. Všetky štyri ihlice predstavujú typ s pečatidlovou hlavicou, pričom sa odlišujú minimálnymi odchýlkami vo výzdobe. Ihlice uložené v popolnici sú na krčku po celom obvode dvojnásobne ryhované. Okrem toho sú d’alšie dve ihlice s pečatidlovou hlavicou zdobené ryhovaním aj na okraji hlavice (Dušek 1980, 343, 344, tab. I; II). Tieto ihlice predstavujú typický šperk strednej doby bronzovej a v prostredí SMK na Slovensku tvoria najpočetnejšie zastúpenú skupinu ihlíc. Na pohrebisku v Smoleniciach ich nachádzame v každom hrobovom celku, dalšie pochádzajú z rozrušených hrobov. Najstaršie prototypy ihlíc s pečatidlovou hlavicou majú prevŕtaný valcovitý krčok a $\mathrm{K}$. Willvonseder ich na základe velmi výrazných ihlíc zo Siedingu z Dolného Rakúska radí do stupňa BB2 (Willvonseder 1937, 115). V. Furmánek datuje menované ihlice do stupňa BB2 z dôvodu ich spoločného výskytu s uzatvorenými srdcovitými záveskami (Furmánek 1973, 151-361). Po posúdení inventára hrobu 13, mohyly 6, možno s určitostou predpokladat dva hroby, ktoré dokladajú existenciu slávnostného odevu prináležiaceho dvom osobám. Bez antropologickej analýzy však možno len uvažovat’ o ich príbuzenskom vzt̉ahu. V prípade obsahu popolnice 2 , teda dvoch párov ihlíc s pečatidlovou hlavicou, štyroch náramkov a dvoch zvitkov zlatého drôtu, je zrejmé, že ide o ženský hrob. Pochovaná ženy mala na každom zápästí po dva náramky. Analogický spôsob nosenia náramkov v pároch je doložený na pohrebisku mohylovej kultúry v Mezöcsáte, a to v prípade ženských hrobov 9, 86, 66 a 77 (Hänsel/Kalicz 1986, 58). Snaha o zachovanie symetrie bola zrejmá. Usporiadanie však nebolo dodržané v detských hroboch 7 a 15. Nový spôsob nosenia náramkov bol doložený v mužskom hrobe 88, kde pár náramkov bol umiestnený na pravom ramene. Na pohrebisku v Mezöcsáte sa teda spôsob nosenia náramkov odlišoval na základe pohlavia. Pravdepodobnost̉ nosenia v pároch dokladá príbuzná vel'kost’ náramkov aj v prípade žiarového hrobu 13, mohyly $6 \mathrm{v}$ Smoleniciach. V troch prípadoch bol priemer $6,5 \mathrm{~cm} v$ jednom $6 \mathrm{~cm}$. Dva páry ihlíc majú taktiež svoje opodstatnenie. Jeden pár slúžil pravdepodobne na zopnutie plášta pochovanej ženy, pričom druhý pár ihlíc mohol slúžit na zopnutie pohrebného vrchného rúcha, do ktorého bola žena zahalená. Spôsob umiestnenia dvoch zvitkov zlatého drôtu je taž̌ko možné bližšie špecifikovat. Možno uvažovat’ o ozdobe vlasov, súčasti textilnej pokrývky hlavy, súčasti odevu, prípadne len o forme hrobovej prílohy. Aj takýmto spôsobom mohlo byṫ vyjadrené sociálne postavenie pochovanej ženy, ktorá nepochybne patrila k elite spoločnosti pochovávajúcej svojich členov na pohrebisku v Smoleniciach. Popolnica 1, ktorá okrem kalcinovaných kostí obsahovala dva bronzové náramky priemeru $6,5 \mathrm{~cm}$ a $5,5 \mathrm{~cm}$, neposkytuje potrebné informácie na bližšie spracovanie, prípadne určenie vzájomných vztahov medzi oboma pochovanými jedincami. Na základe rozdielnych vel'kostí exemplárov, čo platí i v prípade šiestich náramkov uložených v blízkosti popolnice je zrejmé, že ide o detský hrob. Pri tejto dedukcii sa opieram o neprítomnost iného inventára a hlavne variabilitu priemeru náramkov (tri exempláre mali priemer menší než $6 \mathrm{~cm}$ ). Domnienku potvrdzuje aj podstatne menšia vel'kost̉ popolnice 1 oproti popolnici 2 (Dušek 1980, 324). Zaujímavé svedectvo o slávnostnom odeve poskytuje i kostrový hrob 27 z mohyly 12 v Smoleniciach. Kostra bola značne strávená, zachovali sa len kosti nôh a nálezy sa nachádzali v sekundárnej polohe. V mieste lebky ležali dva pozdĺžne rebrované bronzové náramky s rozšírenými koncami. Hrobový inventár tvorilo tiež dvanáste uzatvorených srdcovitých záveskov, devät bronzových špirálových trubičiek z náhrdelníka, bronzový rebrovaný prsteň s prekríženými koncami a jantárové perly. Pri nohách bola umiestnená nádobka a črepy z misy a amfory. I ked' opisovaný celok neobsahoval vo svojom inventári dve ihlice, za kritérium jeho priradenia k ženským hrobom považujem prítomnost’ náhrdelníka pozostávajúceho z dvanástich srdcovitých 
záveskov a špirálových trubičiek. Srdcovité závesky patria medzi typické šperky strednej doby bronzovej. Ich pôvod je v Karpatskej kotline, kde sa vyvíjajú už od staršej doby bronzovej. V prostredí SMK na Slovensku boli objavené v hroboch v Dunajskej Lužnej, Čáčove a Obide. Ďalšie pochádzajú z depotu z Malého Blahova (Budinský-Krička 1950, 1-3). Známych je niekol'ko typov: jednoduché uzavreté závesky, uzavreté závesky so stredovým výbežkom, uzavreté závesky so stredovou priečkou, uzavreté závesky so stredovou priečkou a dvoma výčnelkami (Furmánek 1980; Gašaj 1975, 32, 33). V prípade preberaného hrobu 27 je doložený posledne menovaný typ. Uzavreté srdcovité závesky sú mladšie ako typologicky jednoduchšie otvorené typy. Vyskytujú sa $\mathrm{v}$ priebehu strednej doby bronzovej a ich hlavný výskyt je zaznamenaný až v stupni BC (Novotná 1970, 26). B. Hänsel (1968, 113-115) exempláre so zložitou stredovou priečkou zaradil do stupňov MD II a MD III. Výskyt srdcovitých záveskov už od staršej doby bronzovej potvrdzuje aj G. Schumacher-Matthäusová. Podla zmienenej autorky náhrdelníky pozostávajúce zo srdcovitých záveskov predstavujú typický šperk ženských hrobov. Počet exemplárov býva variabilný, ale na základe analogických vyobrazení na antropomorfných plastikách z oblasti dolného Dunaja predpokladá, že na náhrdelníku bývali usporiadané v dvoch radoch. Špirálové trubičky, boli pravdepodobne rozmiestnené medzi jednotlivými záveskami (Schumacher-Matthäus 1985, 105, tab. 58: 3, 4). Súčastou výbavy hrobu boli aj dva pozdĺžne rebrované náramky. Náramky tohto typu boli rozšírené od Francúzska až po stredný Dunaj. V. Furmánek odvodzuje tento tvar od manžetových náramkov staršej doby bronzovej. Z územia Moravy uvádza niekol'ko nálezísk plechových exemplárov s pozdĺžnym rebrovaním, ktoré sú na základe sprievodných ihlíc datované do stupňa BC (Furmánek 1973, 118). M. Dušek datuje smolenické náramky menovaného typu do stupňa BB 2, s možnostou ich pretrvávania do stupňa BC (Dušek 1980, 361).

\section{ZHRNUTIE}

Pri opise inventára preberaných hrobových celkov nie je možné pochybovat’ o existencii spoločenskej elity v priebehu strednej doby bronzovej. Samotný ženský kroj dokladá, že ide o ženy s vyšším sociálnym a spoločenským statusom. I ked’ charakter šperkov a súčastí odevov má príbuzný ráz na celom území rozšírenia mohylových kultúr v stredodunajsko-karpatskom priestore, predsa je možné pozorovat typické garnitúry šperkov, ktoré informujú o vzhlade slávnostného posmrtného odevu (tabela 1). Dôležitým faktorom je vek pochovaných dievčat a žien, ktorý naznačuje, že slávnostné rúcho prináležalo viacerým vekovým kategóriám (tabela 2). Na pohrebisku v Pittene je možné vyčlenit viac charakteristických súprav. Jedinečnost’ nálezov dokladá skutočnost', že v celom stredodunajsko-karpatskom priestore neboli objavené analógie nálezov, ako to je v prípade inventára hrobov 111a, 26a a 2. Do popredia vystupujú niektoré súpravy šperkov, ktoré je možné začlenit do dvoch skupín:

- súpravy s diadémom a ozdobnými krížovými platňami;

- súpravy s náhrdelníkmi a náramkami.

\section{Súpravy s diadémom a ozdobnými krížovými platňami}

Hrobový inventár je vo svojich rozdieloch nepochybne výslednicou sociálnych rozdielov (Ožd’áni 1986, 52). Kvantitatívna i kvalitatívna stránka hrobovej výbavy bola základným prejavom sociálnej stratifikácie spoločnosti, o čom svedčí prítomnost’ výnimočných diadémov a ozdobných krížových platní v hroboch žien. Uloženie diadémov napravo od lebky môže mat’ symbolický charakter. Vek žien v hroboch s diadémami je 30-45 rokov, rovnako v hrobe 2 bola pochovaná dospelá žena. Vo všetkých prípadoch bol odev zopnutý na pleciach dvoma ihlicami. Za zmienku stojí výskyt tretej ihlice v hrobe 111a pri lavom kolene pochovanej ženy. Predpokladám existenciu posmrtného rúcha, do ktorého bola žena zavinutá. Dosvedčuje to nález menovanej ihlice, ktorá pravdepodobne spínala plášt siahajúci ku lýtkam pri lavom kolene. Rovnako možno uvažovat’ v prípade hrobu 2, kde sa v oblasti pravého bedra nachádzala krížová platnička. Mohla predstavovat okrasný prvok a dodávala pláštu slávnostný a honosný výraz. Pri rekonštrukcii je potrebné brat do úvahy skutočnost', že ide o posmrtný slávnostný odev, ktorý sa v niektorých náležitostiach odlišoval od odevu používaného za života. Preto uvažujem o zahalovaní do posmrtných pláštov, čo je možné preukázat’ vo viacerých prípadoch. Dížku plášta je možné špecifikovat’ vzhl'adom k veku pochovaných žien. O plášti siahajúcom po lýtka je možné uvažovat pri hrobe 111a na nekropole v Pittene. Analogické prípady boli zaznamenané na nekropolách mohylovej 
kultúry v Mezöcsáte (hrob 9; Hänsel/Kalicz 1986, 14, 15, tab. 1; 2) a v Tápé (hrob 444), kde približne rovnakú dížku plášta dokladajú dva rady pukličiek tiahnuce sa v zvislom smere pozdíž pravej stehennej kosti. Tieto mohli vytvárat lem plášta, ktorý skrášloval podkovovitý závesok (Trogmayer 1975, 25, 26, tab. 39; 40). V prípade hrobov s pochovanými mladšími ženami sa potvrdila kratšia dĺžka pláštov, čo dokladajú súčasti lemov - bronzové pukličky, ako napríklad v hrobe 66 na nekropole v Mezöcsáte (Hänsel/Kalicz 1986, 30, 32, tab. 9). Pri týchto hrobových celkoch predpokladám vytiahnutie plášta cez tvár pochovanej. V prípade hrobov 57 a prípadne i 98 v Pittene môže byt tento zvyk doložený prítomnostou vysokých kónických záveskov umiestnených pri lebke pochovaného dievčata.

Tabela 2. Porovnávacia tabela s rozdelením inventára ženských hrobov vzhladom k vekovým kategóriám na nekropole v Pittene.

\begin{tabular}{|c|c|c|}
\hline Pitten - infans II-III & Pitten-juvenis-adultus & Pitten - adultus \\
\hline Hrob 57 & Hrob 17 & Hrob 2 \\
\hline \multirow{3}{*}{$\begin{array}{l}\text { 12-13 rokov } \\
\text { náhrdelník } 1 \\
\text { (10 terčovitých záveskov) } \\
\text { špirálové trubičky } \\
\text { vysoké kónické závesky } 6\end{array}$} & $\begin{array}{l}? \\
\text { ihlica } 3\end{array}$ & \multirow{6}{*}{$\begin{array}{l}\text { ? } \\
\text { krížová ozdobná platnička } 2 \\
\text { ihlica } 2 \\
\text { náhrdelník } 1 \\
\text { (terčovité závesky 11) } \\
\text { špirálové trubičky } \\
\text { hlinený korálik } 2 \\
\text { prsteň } 4\end{array}$} \\
\hline & Hrob 24 & \\
\hline & \multirow{3}{*}{$\begin{array}{l}\text { 15-18 rokov } \\
\text { ihlica } 2 \\
\text { terčovitý závesok } 1\end{array}$} & \\
\hline Hrob 76 & & \\
\hline \multirow{3}{*}{$\begin{array}{l}\text { 12-13 rokov } \\
\text { inlica } 1\end{array}$} & & \\
\hline & Hrob 50 & \\
\hline & \multirow{6}{*}{$\begin{array}{l}\text { 16-20 rokov } \\
\text { ihica } 2 \\
\text { náramok } 2 \\
\text { prsteň } 3 \\
\text { krúžok z bronzového drôtu } 1 \\
\text { šprálové trubičky } \\
\text { špirálka }\end{array}$} & Hrob 26a \\
\hline Hrob $181 \mathrm{c}$ & & \multirow{4}{*}{$\begin{array}{l}\text { 30-35 rokov } \\
\text { diadém } 1 \\
\text { ihlica } 2 \\
\text { závesok } 1 \\
\text { špirálové trubičky } 6\end{array}$} \\
\hline \multirow{6}{*}{$\begin{array}{l}8 \text { rokov } \\
\text { krúžky z bronzového drôtu } 2\end{array}$} & & \\
\hline & & \\
\hline & & \\
\hline & & Hrob 111a \\
\hline & Hrob 98 & \multirow{2}{*}{$\begin{array}{l}\text { 35-45 rokov } \\
\text { diadém } 1 \\
\text { inlica } 3 \\
\text { bronzové krúžky } 2\end{array}$} \\
\hline & $\begin{array}{l}\text { 16-20 rokov } \\
\text { ihlica } 2 \\
\text { náhrdelník } 1 \\
\text { terčovitý závesok } 7 \\
\text { vysoké kónické závesky } 3 \\
\text { špirálové trubičky } \\
\text { prsteň } 2\end{array}$ & \\
\hline
\end{tabular}

\section{Súpravy s náhrdelníkmi a náramkami}

Hroby 57 a 98 na pittenskej nekropole sa vyznačujú spoločným výskytom honosného náhrdelníka pozostávajúceho $\mathrm{z}$ terčovitých záveskov a špirálových trubičiek. Oba hroby obsahovali po dve ihlice a v oboch bola taktiež zistená prítomnost̉ vysokých kónických záveskov. Existujú viaceré možnosti spôsobu aplikácie. Mohli byt umiestnené obdobným spôsobom ako v hrobe 57 . V prípade výskytu troch exemplárov však existuje analógia, napríklad pri rekonštrukcii ženského hrobu 6 z Deteku, kde boli tri závesky navlečené na šnúre z organického materiálu, tá je v zadnej časti hlavy pripevnená na čelenku (Schumacher-Matthäus 1985, tab. 56: 1a, 1b). Na pohrebisku v Pittene bolo pät takýchto záveskov objavených i v hrobe 149. Aj v tomto prípade nálezová situácia nebola priaznivá a nebolo možné určit pohlavie pochovaného jedinca (infans-juvenis). ${ }^{2}$ Takže vo všetkých troch prípadoch išlo o spojitost’ výskytu menovaného typu záveskov s hrobmi jedincov nedospelého veku. Pričom v prípade hrobov 57 a 98 išlo o honosné súpravy. Všetky tri hroby sú datované do strednej fázy mohylovej kultúry (Hampl/ Kerchler/Benkovsky-Pivovarová 1985, 73). Pre označenie súpravy šperkov objavených $\mathrm{v}$ hrobe dievčata z Viedne, ktoré sú radené na počiatok staršej fázy mohylovej kultúry, je typickým opät výskyt náhrdel-

\footnotetext{
2 Išlo o žiarový hrob, ktorého súčastou inventára bola jedna ihlica. Pravdepodobne ide o hrob jedinca mužského pohlavia.
} 
níka, ktorý v tomto prípade pozostával až z osemnástich terčovitých záveskov. Honosný kroj dotvárali dve kosákovité ihlice, dva nárameníky a dva nánožníky. Celý hrobový celok bol už opísaný, a tak iba dodám, že je krásnou ukážkou pohrebného slávnostného kroja a poskytuje možnost̉ presnej predstavy aplikácie a funkcie šperku na odeve zo samotného počiatku strednej doby bronzovej. K tomuto typu môžeme priradit’ aj inventár mušovského depotu. Do skupiny súprav s náhrdelníkmi a náramkami možno začlenit aj súbor šperkov z hrobu 13 z mohyly 6 z pohrebiska v Smoleniciach. Je datovaný do záveru strednej s prežívaním v mladšej fáze mohylovej kultúry. Charakteristický je inventár objavený v popolnici 2. Ženu zdobili štyri náramky, pravdepodobne vždy po dva na každom zápästí. Štyri ihlice spínali plášte. Mohlo íst’ o viacvrstvový odev, čo by vysvetlovalo prítomnost' dvoch párov ihlíc. Dva zvitky zlatého drôtu mali mnohostranné využitie. Slúžili ako súčast' ozdoby vlasov, prípadne pokrievky hlavy z organického materiálu. Tento predpoklad podporuje analogický výskyt dvoch zlatých špirálok 27-31-ročnej ženy, v hrobe 88 na pohrebisku v Mezöcsáte (Hänsel/Kalicz 1986, 38, 39, tab. 12; 88a, b). Boli uložené vo frontálnej oblasti lebky a pod čelustou, pričom sekundárne premiestnenie vylučuje kúsok sánky pri jednom z exemplárov. Evidentné je nosenie v pároch a symetrické uloženie.

Pri opisovaných garnitúrach šperkov je na prvý pohlad zrejmé, že skupina s diadémom a ozdobnými krížovými platničkami je zastúpená podstatne nižším počtom hrobových celkov, než skupina s náhrdelníkmi a náramkami. Je zrejmé, že ak bol súčastou kroja honosný a výnimočný šperk, ktorý vyjadroval náležité spoločenské postavenie, nebolo nutné odev dopĺn̆at d’alšími šperkmi, prípadne súčastami odevu. Druhá skupina, s náhrdelníkmi a náramkami, sa javí ako početnejšie zastúpená, pričom súčastou kroja boli šperky bežne sa vyskytujúce $\mathrm{v}$ prostredí mohylových kultúr. $\mathrm{V}$ tomto prípade je však zretelne doložená kvantita nálezov, čo kompenzovalo neprítomnost̉ tzv. výnimočných exemplárov. Z objektívnych príčin sa zachovala iba čast̉ materiálu radeného do obdobia strednej doby bronzovej, ktoré odolali pôsobeniu prírodných faktorov a vplyvu času. Aj v priebehu vývoja mohylových kultúr je potrebné rátat’ s faktom, že prevažná väčšina predmetov bola zhotovená z organických materiálov, ktoré sa nezachovali, na rozdiel od nálezov bronzov. Možné je tiež poukázat’ na skutočnoste, že existujú rozdiely medzi jednotlivými súpravami šperkov a súčastami odevov, ktoré sú podmienené vekom pochovaných žien. Najpriaznivejšou pre riešenie tejto problematiky bola práve situácia na pohrebisku v Pittene. Pre hrobové celky boli vypracované antropologické analýzy s udaním veku pochovaných dievčat i žien a inventár jednotlivých hrobov je možné názorne porovnat' (tabela 2). Najchudobnejšie boli vybavené hroby dievčat vo veku infans II (hroby 76 a 181e). Výnimkou bol hrob 57, v ktorom pochované 12-13-ročné dievča vlastnilo honosný náhrdelník z desiatich terčovitých záveskov a špirálových trubičiek. Viditelný nárast šperkov je zaznamenaný vo vekovej skupine juvenis-adultus, oproti skupine infans II-III. Hrob 50, v ktorom bola pochovaná mladá 16-20-ročná žena obsahoval okrem dvoch ihlíc dva náramky, špirálové trubičky a prstene. Tiež hrob 98, patriaci žene rovnakého veku obsahoval náhrdelník z terčovitých záveskov, špirálových trubičiek, dve ihlice, prstene a tri vysoké kónické závesky. Rozdiely sú zrejmé a možno ich potvrdit’ aj popri výnimke hrobu 57. Skutočnost', že bohatý kroj vlastnilo mladé dievča je možné vysvetlit rôzne. Tento hrobový celok sa odlišuje od ostaných na pohrebisku napríklad zoskupením šiestich vysokých kónických záveskov za hlavou dievčata. Obdobné typy záveskov sa vyskytli na pohrebisku len $\mathrm{v}$ troch hroboch, napríklad $\mathrm{v}$ bohatom hrobe 98 . Už to poukazuje prinajmenšom na výnimočné postavenie dievčata $\mathrm{v}$ spoločnosti. $\mathrm{V}$ neposlednom rade je potrebné vziat do úvahy možnost̉ vyššieho veku, než ktorý bol udaný antropologickou analýzou. Výrazný rozdiel v charaktere kroja je doložený u dospelých žien, veku adultus, prípadne adultus-maturus. V príspevku opisované hroby 2, 26a a 111a sú toho jedinečným dôkazom. Vo všeobecnosti možno skonštatovat', že bohatstvo šperkov a súčastí odevu, ktoré dotvárali kroj dievčat a žien mohylových kultúr je podmienený vekom. K dosiahnutiu objektívnych výsledkov je však potrebná náležitá antropologická analýza. Rozdiely v rámci vekových skupín je potrebné doložit spracovaním konkrétnej spoločnosti, resp. jednotky pochovávajúcej svojich členov na určitom pohrebisku. Až prostredníctvom týchto výsledkov je reálne d’alšie vyhodnotenie na úrovni vyšších spoločenských jednotiek medzi jednotlivými pohrebiskami a ich následné zhodnotenie. 

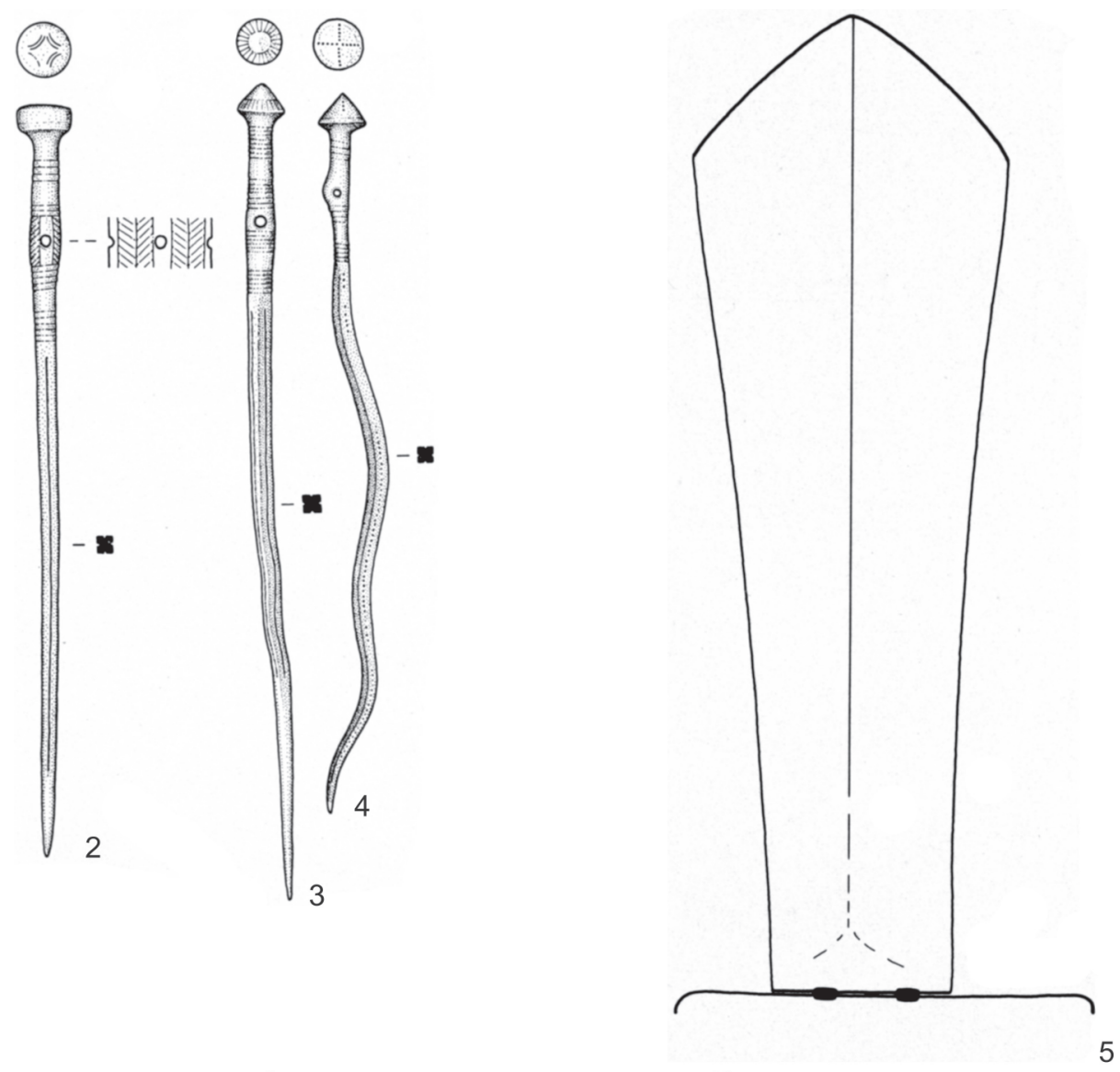

0 $10 \mathrm{~cm}$
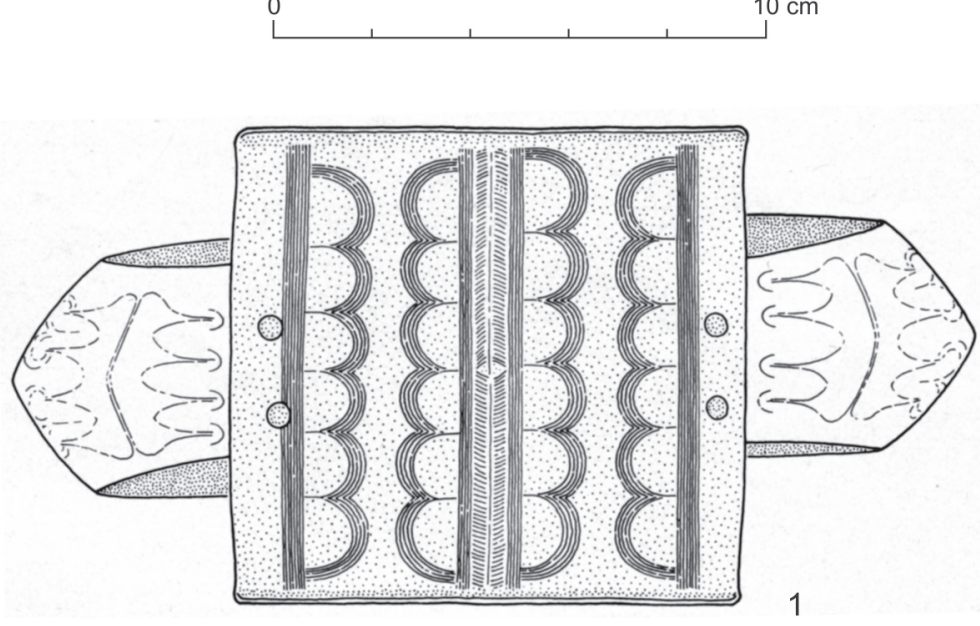

Tab. I. Pitten. Hrob 111a, výber bronzových predmetov (podla Hampl/Kerchler/Benkovsky-Pivovarová 1978-1981, tab. 216: 5-7; 217). 


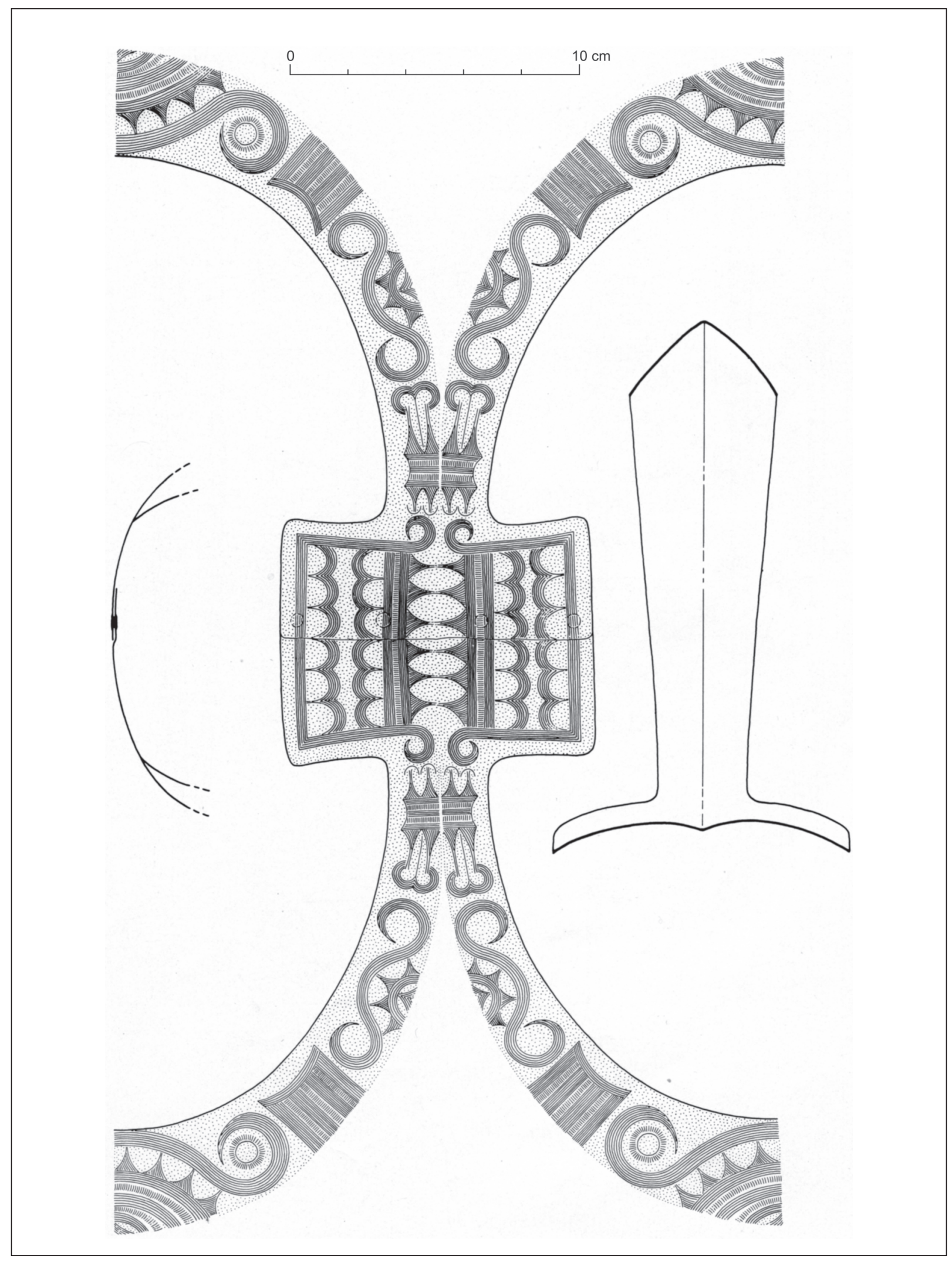

Tab. II. Pitten. Hrob 26a, diadém so zobrazením výzdoby (podla Hampl/Kerchler/Benkovsky-Pivovarová 1978-1981, tab. 204). 


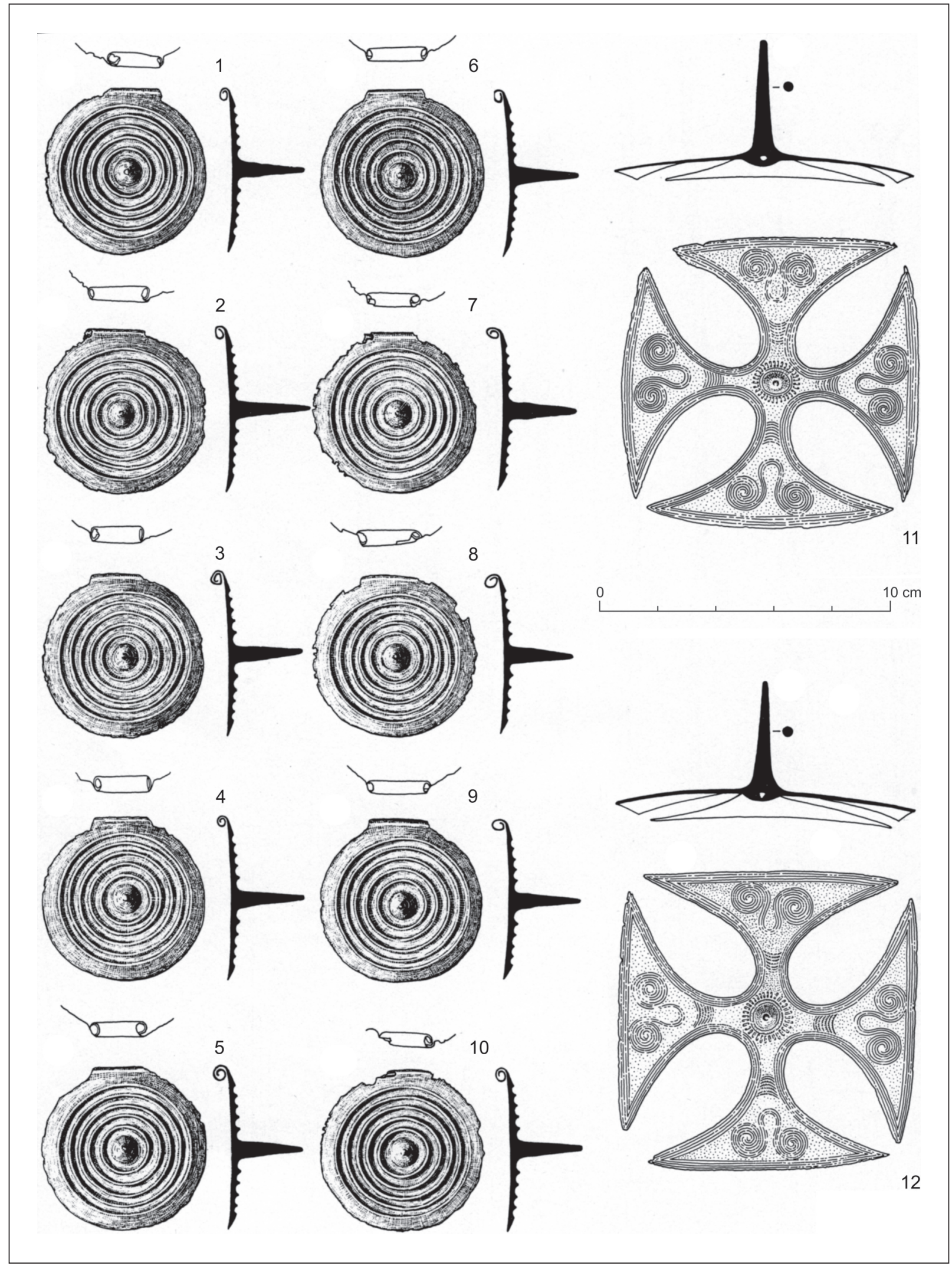

Tab. III. Pitten. Hrob 2, výber bronzových predmetov (podl’a Hampl/Kerchler/Benkovsky-Pivovarová 1978-1981, tab. 197: $1-12)$. 


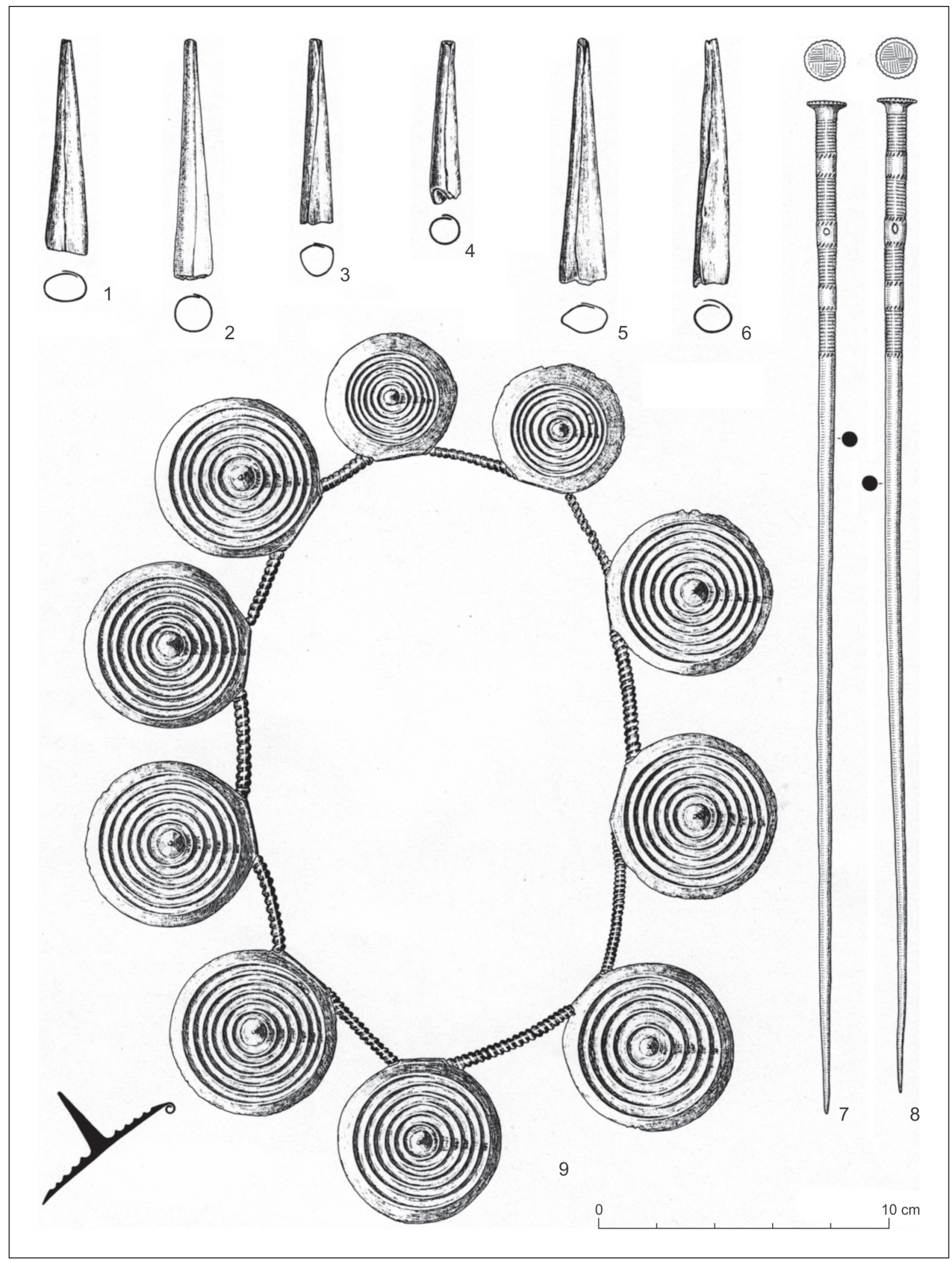

Tab. IV. Pitten. Hrob 57, výber bronzových predmetov (podla Hampl/Kerchler/Benkovsky-Pivovarová 1978-1981, tab. 209: 3-10, 12). 


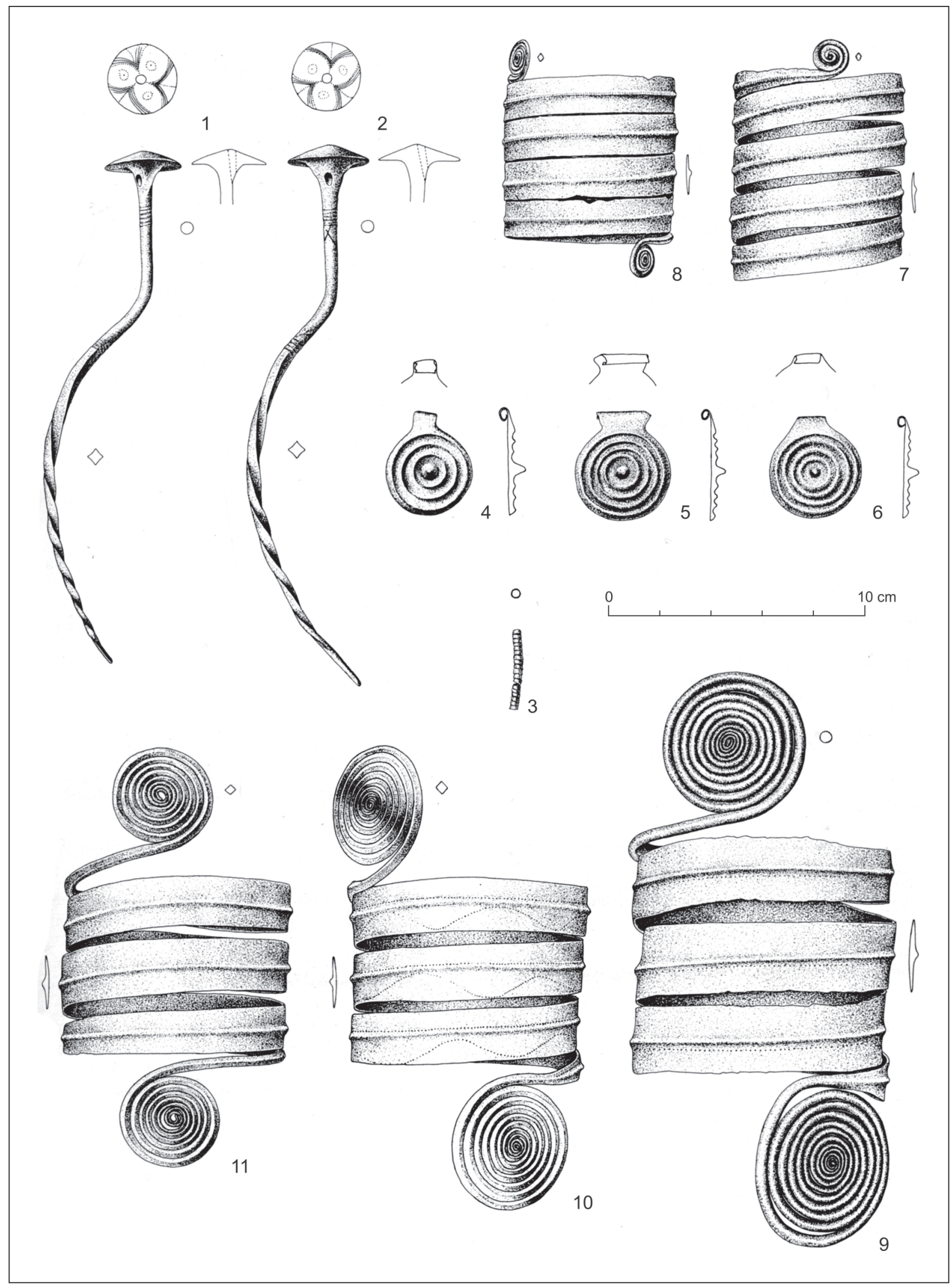

Tab. V. Viedeň 23-Sulzengasse. Hrob, výber bronzových predmetov (podla Hahnel 1994, obr. 1; 3). 


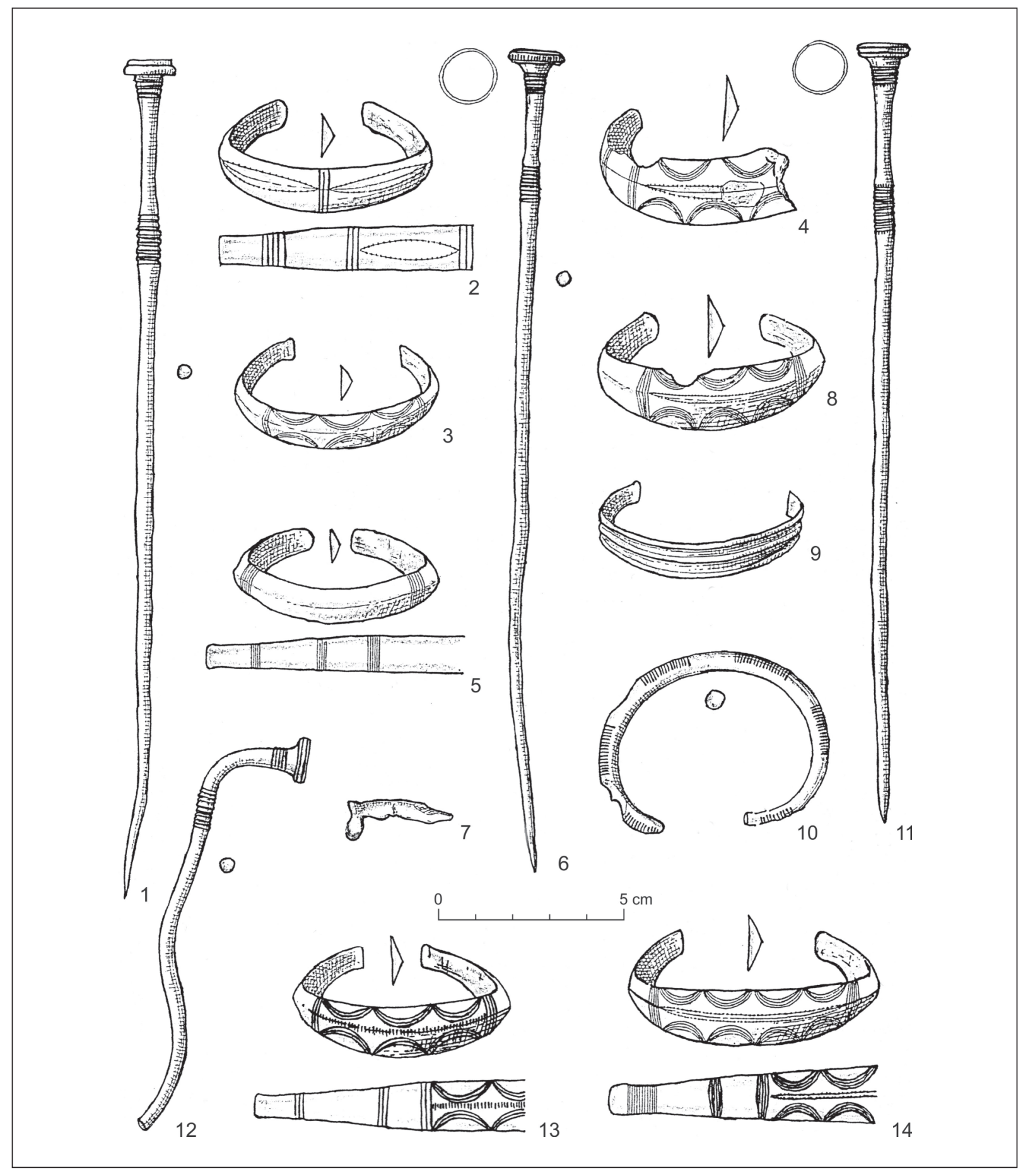

Tab. VI. Smolenice. Hrob 13, mohyla 6, výber bronzových predmetov (podla Dušek 1980, tab. 2: 1-14). 


\section{LITERATÚRA}

Angeli 1961

Bašta/Baštová/Metlička 1990

Benkovsky-Pivovarová 1984

Benkovsky-Pivovarová 1994

Benkovsky-Pivovarová 2016

Brunn 1976

Budinský-Krička 1950

Červinka 1926

Dušek 1980

Eisner 1933

Furmánek 1973

Furmánek 1980

Furmánek/Veliačik/Vladár 1991 Furmánek/Ožd’áni 2015

Gašaj 1975

Hahnel 1994

Hachmann 1957

Hampl/Kerchler/Benkovsky-Pivovarová 1978-1981

F. Hampl/H. Kerchler/Z. Benkovsky-Pivovarová: Das mittelbronzezeitliche Gräberfeld von Pitten in Niederösterreich. Mitteilungen der Prähistorischen Kommission 19-20. Wien 1978-1981.

Hampl/Kerchler/Benkovsky-Pivovarová 1985

F. Hampl/H. Kerchler/Z. Benkovsky-Pivovarová: Das mittelbronzezeitliche Gräberfeld von Pitten in Niederösterreich. Mitteilungen der Prähistorischen Kommission 21-22. Wien 1982-1985.

Hänsel 1967

Hänsel 1968

Hänsel/Kalicz 1986

Innerhofer 2000

Jílková 1958

Lichardus/Vladár 1997

Mozsolics 1967

Mozsolics 1973

Nevizánsky/Prohászka 2017

W. Angeli: Der Depotfund von Stockerau (Niederösterreich). Mitteilungen der Anthropologischen Gesellschaft in Wien 91, 1961, 141.

J. Bašta/D. Baštová/M. Metlička: Osídlení mikroregionu v polohe Čemínskeho potoka v době bronzové. Archeologické rozhledy 52, 1990, 147-153.

Z. Benkovsky-Pivovarová: K otázke datovania a kultúrneho postavenia kosákomile Kraskovskej (k životnému jubileu). Bratislava 1984, 30-37.

Z. Benkovsky-Pivovarová: Zur Lokalisierung des bronzezeitlichen „Depotfundes aus Stockerau“. Archaeologia Austriaca 78, 1994, 21-23.

Z. Benkovsky-Pivovarová: K terminológii počiatku strednej doby bronzovej na juznom Slovensku vo svetle nálezov z hrobu 3/62 mad’arovskej kultúry z Nových Zámkov. Zborník SNM 110. Archeológia 26, 2016, 19-26.

W. A. von Brunn: A. Mozsolics: Bronze- und Goldfunde des Karpatenbekens. Depotfundhorizonte von Forró und Opályi. 1970. Germania 54, 1976, $227-237$. ská Streda. Časopis Muzeálnej slovenskej spoločnosti 41, 1950, 1-3.

Reallexikon der Vorgeschichte 2. Berlin 1925, 348.

M. Dušek: Pohrebisko ludu stredodunajskej mohylovej kultúry v Smoleniciach. Slovenská archeológia 28, 1980, 341-382.

J. Eisner: Slovensko v pravěku. Bratislava 1933.

V. Furmánek: Bronzová industrie středodunajské mohylové kultury na Moravě.

. Furmánek: Die Anhänger in der Slowakei. Prähistorische Bronzefunde XI/3. München 1980.

V. Furmánek/L. Veliačik/J. Vladár: Slovensko v dobe bronzovej. Bratislava 1991.

V. Furmánek/O. Ožd’áni: Mohylové kultúry. Kov. In: V. Furmánek (zost.): Staré Slovensko 4. Doba bronzová. Nitra 2015, 149-156.

D. Gašaj: Stredodunajská mohylová kultúra na Slovensku. Diplomová práca (Univerzita Komenského). Bratislava 1975. Nepublikované.

B. Hahnel: Funde der mittleren Bronzezeit, der älteren Urnenfelderzeit sowie der Spätlatene- und Römerzeit in Wien 23, Sulzengasse. Archaeologia Austriaca 78, 1994, 29-32.

R. Hachmann: Die frühe Bronzezeit im westlichen Ostseegebeit und ihre mittel- und südosteuropäischen Beziehungen 6. Beiheft zum Atlas der Urgeschichte. Hamburg 1957.

B. Hänsel: Ein Hortfund der älteren Mittelbronzezeit aus Hodonín (Goding) in Mähren. Mitteilungen der Anthropologieschen Gesellschaft in Wien 96/97. Wien 1967, 275-289.

B. Hänsel: Beiträge zur Chronologie der mittleren Bronzezeit im Karpatenbecken I-II. Bonn 1968.

B. Hänsel/N. Kalicz: Das bronzezeitliche Gräberfeld von Mezöcsát. Kom. Borsod, Nordostungarn. Bericht der Römisch-Germanischen Kommission 67, 1986, 6-88.

F. Innerhofer: Die mittelbronzezeitlichen Nadeln zwischen Vogesen und Karpaten I, II. Bonn 2000.

E. Jílková: Najstarší a najmladší horizont západočeské mohylové keramiky na pohřebišti v Plzni-Nové Hospodě. Památky archeologické 49, 1958, 312-347.

J. Lichardus/J. Vladár: Frühe und mittlere Bronzezeit in der Südwestslowakei. Forschungsbeitrag von Anton Točík. Slovenská archeológia 45, 1997, 221-352.

A. Mozsolics: Bronzefunde des Karpatenbeckens. Budapest 1967.

A. Mozsolics: Bronze- und Goldfunde des Karpatenbeckens. Budapest 1973.

G. Nevizánsky/P. Prohászka: Hrobové nálezy únětickej kultúry z roku 1898 v Šenkviciach. Slovenská archeológia 65, 2017, 195-206. 
Novotná 1970

Novotná 1980

Novotná 1993

Novotná 1999

Ožd’áni 1986

Paulík 1986

Patay 1954

Pichlerová 1957

Říhovský 1979

Schumacher-Matthäus 1985

Stuchlík 1981

Stuchlík 1990a

Stuchlík $1990 b$

Torbrügge 1959

Trogmayer 1975

Willvonseder 1937
M. Novotná: Die Bronzehortfunde in der Slowakei. Bratislava 1970.

M. Novotná: Die Nadeln in der Slowakei. Prähistorische Bronzefunde XII/6. München 1980.

M. Novotná: Doba bronzová. In: T. Štefanovičová a kolektív: Najstaršie dejiny Bratislavy. Bratislava 1993, 80-117.

M. Novotná: Beiträge zur Besiedlung der Mitteldanubischen Hügelgräberkultur in der Slowakei. In: J. Bátora/J. Peška (ed.): Aktuelle Probleme der Erforschung der Frühbronzezeit in Böhmen und Mähren und in der Slowakei. Nitra 1999, 241-249. O. Oždáni: Zur Problematik der Entwicklung der Hügelgräberkulturen in der Südwestslowakei. Slovenská archeológia 34, 1986, 5-96.

J. Paulík: Čačianska mohyla v Dedinke, okres Nové Zámky. Zborník SNM 80, História 26, 1986, 69-112.

P. Patay: Előzetes jelentés a nagybátonyi temető ásatásának eredményeiről. Archaeologiai Értesitó 81, 1954, 33-49.

M. Pichlerová: Ojedinelé bronzové nálezy zo západného Slovenska. Študijné zvesti AÚ SAV 2, 1957, 65-70.

J. К̌íhovský: Die Nadeln in Mähren und im Ostalpengebiet. Prähistorische Bronzefunde XIII/5. München 1979.

G. Schumacher-Matthäus: Studien zu bronzezeitlichen Schmucktrachten im Karpatenbecken. Marburger Studien zur Vor- und Frühgeschichte 6. Hildesheim 1985. S. Stuchlík: Depot středodunajdské mohylové kultury z Mušova. Archeologické rozhledy 33, 1981, 361-370.

S. Stuchlík: Die bisherigen Ergebnisse der Erforschung des Hügelgräberfeldes in Borotice. Archeologické rozhledy 42, 1990, 159-169, 227, 228.

S. Stuchlík: Die Entstehung der Hügelgräberkultur in Mähren und ihre Entwicklung. In: V. Furmánek/F. Horst (Hrsg.): Beiträge zur Geschichte und Kultur der mitteleuropäischen Bronzezeit. Berlin - Nitra 1990, 469-481.

W. Torbrügge: Die Bronzezeit in Oberpfalz. Kallmünz 1959.

O. Trogmayer: Das bronzezeitliche Gräberfeld bei Tápé. Fontes Archaeologici Hungariae. Budapest 1975.

K. Willvonseder: Die mittlere bronzezeit in Österreich. Wien - Leipzig 1937.

\title{
Bronze components of ceremonial female costume of the Middle-Danube Barrow culture
}

\author{
Andrea Slaná
}

Summary

During the Middle Bronze Age, the quantitative and qualitative aspects of grave goods were the primary manifestations of social stratification. However, this image was affected for example by grave robberies. Only a part of the finds which withstood the effects of natural factors and the impact of time has been preserved for objective reasons. Based on the structure of the gifts given to the deceased, it is now possible to distinguish the abundant grave units that vary from others within the framework of the individual burial grounds. As far as the female graves are concerned, there is an obvious difference in the presence of bronze objects that illustrate the female costume of the time. The objects of the research were the ornaments and functional jewels from the territory settled by the people of the Middle Danube Barrow culture (hereinafter referred to as MBC). When selecting the grave units author of the contribution took into consideration also the anthropological analyses and the structure of the grave inventory which was distinguished by the goods' abundance, uniqueness and where appropriate also the singularity of the material they were made of. The author worked with grave units from the following locations: Pitten, Smolenice, Vienna 23-Sulzengasse, Borotice and with the hoard finds of bronze items in Mušov (Pl. I). The material contents of the researched grave units were very similar; however, it was still possible to distinguish the jewels' peculiar garnitures which were divided into two groups. First set contains the diadem and ornamental cross plates, while the second set includes the necklace and bracelets. The largest variability of the finds within the individual phases of the Barrow culture was found in the burial grounds MBC of Pitten. The two most impressive graves were 111a (Pl. I: 1-4) and 26a (Pl. II). They included the diadems to which there hasn't been found an analogy anywhere in the Middle Danube-Carpathian region. They were 
located solely in the graves of women. Finds of the ornamental plates in the shape of Maltese cross were unique as well. They share similar ornament characteristics with the diadems. They were found in an abundant female grave 2 (Pl. III: 11, 12), but they have also been recorded in some male graves, too. Because of the early stage of the barrow culture it's very problematic to determine which items were acquired by trade and which items came from the local craftsmen. Analogous finds of the diadems from Pitten (graves 111a and 26a) were recorded as far as in the territory of Northern Italy. Nevertheless, similar ornamentation present on the rest of the unique specimens, cross discs (grave 2) suggests the possibility of a local design. The most numerous was the second group - sets with necklace and bracelets. Both graves 57 (Pl. IV: 1-9) and 98 from the burial ground in Pitten were included and also the grave 2 from Vienna 23-Sulzengasse (Pl. V: 1-10) along with the grave I from the mound 9 in Borotice. From the locality in Smolenice it was the grave 27 from mound 12, grave 13 from mound 6 (Pl. VI) and the inventory of the hoard find from Mušov. According to the results of the author of the contribution it is possible to point out to the fact that there are differences between the individual sets of jewellery and parts of the costumes which are conditioned by age of the buried individuals of female gender (Pl. II).

The most favourable situation for dealing with this issue was at the burial grounds in Pitten. Also in this case the least equipped graves were of girls aged: infans II (graves 76 and 181c). The grave 57, where a 12-13 years old girl was buried and owned an opulent necklace made of ten racket pendants and spiral tubes (Pl. IV: 9). As opposed to the age group infans II, a significant increase in the amount of jewellery is recorded with the age group juvenis-adultus. The grave 98 which belonged to a woman of this age group consisted of a necklace made of racket pendants, spiral tubes, two pins, rings and three long conic pendants. A substantial difference in the costume features is recorded with the adult women (adultus, or adultus-maturus). The graves 2, 26a and 111a that are described in the contribution are a supporting evidence of this statement. Author of the contribution reflects also on the covering up with the death cloaks which has been recorded in most of the cases. The length of the cloak seems to be very intriguing as well as it could be specified with regard to the age of the deceased women. The author also reflects on an estimated length of a cloak that came down to the calves based on the situation in the grave 111a in Pitten where the pin that pinned the cloak was situated at the area of the left knee (Pl. I: 4). There is also a possibility of a cloak that would be covering all body with a face covered up, too. This alternative is supported by the presence of long conic pendants situated next to the skull of buried girls in the graves 57 and 98 in Pitten (Pl. IV: 1-6). The plentiful inventory illustrating unique and beautiful jewellery, diadems and ornamental cross discs belonged to women who played an important role in the society. We can therefore conclude that in general, the richness of the jewels and costume components that complete the costume of Barrow culture girls and women is conditioned by age.

Pl. I. Pitten. Grave 111a, selection of bronze items (after Hampl/Kerchler/Benkovsky-Pivovarová 1978-1981, pl. 216: 5-7; 217). Pl. II. Pitten. Grave 26a, diadem with the portrayal of the ornaments (after Hampl/Kerchler/Benkovsky-Pivovarová 19781981, pl. 204).

Pl. III. Pitten. Grave 2, selection of bronze items (after Hampl/Kerchler/Benkovsky-Pivovarová 1978-1981, pl. 197: 1-12).

Pl. IV. Pitten. Grave 57, selection of bronze items (after Hampl/Kerchler/Benkovsky-Pivovarová 1978-1981, tab. 209: 3-10, 12). Pl. V. Vienna 23-Sulzengasse. Grave, selection of bronze items (after Hahnel 1994, fig. 1; 3).

Pl. VI. Smolenice. Grave 13, barrow 6, selection of bronze items (after Dušek 1980, tab. 2: 1-14).

Table 1. Processed grave units' inventory and the deposit of the MBC territories with buried individuals' age specified. Table 2. Comparative table with the female grave's inventory divided according to the age categories found at the Pitten necropolis.

Translated by Jana Eldesová

Mgr. Andrea Slaná, PhD.

Považské múzeum v Žiline

Topolová 1

SK - 01003 Žilina

slana@pmza.sk 
